\author{
Ewa Konefał \\ Uniwersytet Gdański \\ ekonefal@ug.edu.pl
}

\title{
W POSZUKIWANIU METODOLOGII BADAŃ METAPRZEKŁADOZNAWCZYCH
}

DOI: http://dx.doi.org/10.12775/RP.2019.012

\begin{abstract}
Zarys treści: W artykule podjęto próbę zdefiniowania ram metodologicznych badań nad dziejami nauki o przekładzie. Najwłaściwsze w tym przypadku wydaje się połączenie perspektywy historycznej z metodami wykorzystywanymi w naukoznawstwie oraz filozofii nauki. Zapleczem materiałowym do analizy i dalszej syntezy winna stać się kompletna dziedzinowa bibliografia retrospektywna, pozwalająca scalić wiedzę o przekładzie rozproszoną w wielu paradygmatach rozwijanych w ramach różnych dziedzin nauki, wyodrębnić główne pola i zagadnienia badawcze oraz określić ilościowy i jakościowy poziom ich opracowania.
\end{abstract}

Słowa kluczowe: nauka o przekładzie, historiografia, metodologia badań historyczno-przekładoznawczych, bibliografia dziedzinowa, bibliometria

Прошлое научной мысли рисуется нам каждый раз в совершенно иной и все новой перспективе. Каждое научное поколение открывает в этом прошлом новые черты (...) ${ }^{1}$ (Vernadskiy 1904/1988: 180)

D ziałalność naukowa na pewnym etapie rozwoju dyscypliny, w ramach której jest prowadzona, nieuchronnie implikuje refleksję o niej samej: jej przeszłości, zgromadzonym dorobku i metodologii (zob. Kolasa 2013: 5). Pojawianie się takich metarefleksji, np. w postaci pogłębionych syntez bądź historiografii, uważane jest za probierz dojrzałości dyscyplinarnej (White 2002: 191 za D’hulst, Gambier 2018: 3-4; Kolasa 2013: 11). Współczesne badania

${ }^{1}$ Przeszłość myśli naukowej rysuje się nam każdorazowo w zupełnie odmiennej, nowej perspektywie. Każde pokolenie badaczy odkrywa w tej przeszłości nowe cechy (...) [przekład - E.K.]. 
metaprzekładoznawcze naturalną siłą rzeczy winny być ufundowane na dalszej oraz bliższej historii nauki o przekładzie.

$\mathrm{Na}$ każdym etapie ewolucji nauki o przekładzie zainteresowanie badaczy historią działalności translatorskiej i myśli przekładoznawczej było w różny sposób motywowane. W momencie kształtowania się podstaw teoretycznych przekładoznawstwa wynikało z pilnej potrzeby osadzenia nowej nauki na doświadczeniu całej rzeszy tłumaczy i krytyków, dążenia do nadania jej autentyczności. Próby rekonstrukcji dawnych obserwacji nt. przekładu oraz myśli z nim związanej obserwowane są od wczesnonaukowego okresu dyscypliny.

W tym miejscu należałoby poruszyć istotną kwestię periodyzacji w historiografii nauki o przekładzie, która należy do najbardziej spornych (zob. m.in. Kopanev 1972; Steiner 1975/2018; Rener 1989; Ojcewicz 1991; Kostikova 2011; Rundle 2019). W dziejach dyscypliny można wyodrębnić okres przednaukowy, wczesnonaukowy (zob. Ojcewicz 1991: 7-8) oraz naukowy. Przyjmuję, że początek refleksji wczesnonaukowej nastąpił wraz z narodzinami dyskusji akademickiej wokół zagadnień przekładu. W odniesieniu do przekładoznawstwa rosyjskiego, którego dziejami jestem szczególnie zainteresowana, jest to koniec XIX stulecia. Stadium naukowe rozpoczyna się natomiast $\mathrm{w}$ połowie lat 50. ubiegłego stulecia.

Jednym z pierwszych obszarów, który przyciągnął uwagę historyków przekładu, były tłumaczenia biblijne (Chistovich 1873; Gruzinskiy 1912; Yevseyev 1916; Norlie 1934 za: St. André 2011: 135). Podobnym zainteresowaniem badawczym cieszyły się dzieje przekładu literackiego. Pierwszy zarys historii przekładu w literaturze zachodnioeuropejskiej i rosyjskiej, opracowany przez jednego z pierwszych rosyjskich teoretyków przekładu początku XX stulecia - Michaiła Aleksiejewa², został zaprezentowany w 11-tomowej encyklopedii literatur (Smirnov, Alekseyev 1934: 516-526). Historia przekładu i myśli translatorskiej zajmowała w badaniach rosyskojęzycznych kluczową pozycję od momentu konstytuowania się dyscypliny. Andriej Fiodorow w wydanym w 1953 roku wprowadzeniu do teorii przekładu wyodrębnił historię jako pierwszą (!) z subdziedzin przekładoznawstwa (obok ogólnej i szczegółowej teorii przekładu), argumentując to tym, że żadna nauka nie może funkcjonować bez oparcia na doświadczeniu przeszłości (Fedorov 1953: 15)3. Odniesienie do historii - zdaniem tej jednej z najwybitniejszych

2 Aleksiejew już wcześniej, w 1927 r., w wykładzie poświęconym zagadnieniom przekładu literackiego wygłoszonym podczas inauguracji roku akademickiego na Uniwersytecie Irkuckim wyraźnie nawiązywał do dziejów dawnej myśli o przekładzie (Alekseyev 1931: 9-18).

${ }^{3}$ Koncepcja Fiodorowa znacznie więc wyprzedzała przywoływany dość powszechnie w an- 
postaci rosyjskiej nauki o przekładzie - z jednej strony pozwala uniknąć błędów translatorskich, z drugiej - dostarcza wzorców godnych powielenia. Autor zaczyna wprowadzenie od rysu historycznego przedstawiającego spór wokół zagadnienia przekładalności w literaturach zachodnich (od Cycerona po Goethego) - poprzez opis działalności translatorskiej w Rosji (do końca XIX wieku) - kończąc na dość ubogiej jeszcze w tamtym momencie praktyce i teorii przekładu w Rosji Radzieckiej (Fedorov 1953: 19-62). W 1960 roku pod redakcją Fiodorowa i Jurija Lewina ukazała się znakomita, dziś nieco zapomniana, antologia przybliżająca opinie na temat sztuki translatorskiej ludzi pióra i zarazem znakomitych tłumaczy literatury obcej XVII-XX w. - od Dmitrija Kantemira po Maksyma Gorkiego (który wprawdzie tłumaczem nie był, ale w znaczny sposób przyczynił się do rozwoju tłumaczeń literackich na początku XX w.) (Levin, Fedorov 1960). Wspomniany Ju. Lewin w 1962 na łamach cyklicznej monografii Masterstvo pierievoda ${ }^{4}$ postulował stworzenie syntetyzującej historii przekładu w Rosji, osadzonej w kontekście kulturowo-historycznym, mającym - zdaniem autora - niebagatelny wpływ na kształtowanie się myśli translatorskiej, natomiast stworzenie takiej historii zaliczał do ważniejszych zadań ówczesnego literaturoznawstwa (Levin 1962: 373). Istotnym uzupełnieniem badań historyczno-przekładowych stały się szkice gruzińskich badaczy Dawida Gociridze i Georgija Huhuni, obejmujące etapy ewolucji zachodnioeuropejskiej i rosyjskiej sztuki translatorskiej od antyczności do czasów radzieckich (Gotsiridze, Khukhuni 1986).

W latach 60. i 70. XX wieku badacze radzieccy zaczęli przykładać wagę do określenia podstaw metodologicznych badań historycznych nad przekładem literackim, sytuując je na pograniczu historii literatury, i szerzej - rosyjskiej kultury (patrz Levin 1963; Rossel's 1964; Shor 1973). Znaczny wkład do rosyjskiej historiografii tłumaczeń wniosły również liczne tzw. mikrohistorie, przybliżające dzieje konkretnych przekładów lub przekłady jednego twórcy/ tłumacza badane $\mathrm{w}$ ramach literaturoznawczo zorientowanych rosyjskojęzycznych badań nad przekładem 5 .

Koniec ubiegłego stulecia przyniósł znaczny wzrost zainteresowania badaniami historycznymi prowadzonymi na gruncie przekładoznawstwa. Badacze, przede wszystkim zachodni, zaczęli coraz wyraźniej mówić o hi-

glo- i francuskojęzycznej literaturze przedmiotu postulat A. Bermana o konieczności stworzenia historii tłumaczenia jako priorytetowego zadania nowoczesnej teorii tłumaczenia (Berman 1984: 12).

${ }^{4}$ Ta seria wydawnicza była w latach 60 . i 70. ważnym forum prezentacji refleksji historycznej nad przekładem literackim.

${ }^{5}$ Patrz bibliografia autoreferatów dysertacji prezentujących wyniki badań nad przekładem powstałych w ramach specjalności literaturoznawczych (Konefał 2016: 88-304). 
storii przekładu jako perspektywicznej subdyscyplinie studiów przekładoznawczych. Jednak pomimo coraz chętniej podejmowanych inicjatyw badawczych, historia nauki o przekładzie, jak uważają D’hulst i Gambier, nadal znajduje się w stadium początkowym, wyraźnie odczuwalny jest brak badań historycznych, które odnoszą się do ewolucyjnej logiki zmienności, ekspansji i interdyscyplinarności dyscypliny (D’hulst, Gambier 2018: 2). Rzeczywiście należałoby zgodzić się z autorami (tamże), że spora część zgromadzonej od końca ubiegłego wieku literatury z zakresu historii przekładu i badań nad nim ogranicza się do publikacji prezentowanych w formie odrębnych rozdziałów w akademickich teoriach przekładu lub wprowadzeniach do nich (m.in. Garbovskiy 2004; Tyulenev 2004; Bassnett 2005; Modestov 2006; D'hulst 2010; Gambier, Doorslaer 2013; Munday 2016; Shadrin 2017), encyklopediach (Baker, Saldanha 1998/2009/2019) oraz zyskujących na popularności antologiach (m.in. Weissbort, Eysteinsson 2006; Bukowski, Heydel 2009; 2013; Venuti 2012; Bednarczyk 2016: 141-222).

Wymienione opracowania o wyraźnym profilu dydaktycznym stanowią jednakże niewielki pierwiastek prac współcześnie prezentujących dzieje przekładu i myśli translatorskiej. Nie sposób wymienić ich wszystkich. Są one wynikami indywidualnych przedsięwzięć badawczych i wielkich projektów, np. wznawiane trzykrotnie, wydawane w języku francuskim i angielskim dzieło Translators Through History / Les traducteurs dans l'histoire (Delisle, Woodsworth, m.in. 1995/2012). Organizowane są międzynarodowe sympozja (np. Schippel, Zwischenberger 2017) i powstają specjalne wydania czasopism poświęcone historii, m.in. „TTR: Traduction, terminologie, rédaction” (t. 6, nr 1/1993), „The Translator” (t. 20, nr 1/2014), wiele numerów periodyku „Meta”, trzy woluminy polskiego „Przekładańca” (36 i 37/2018, 21/2008). Należałoby tu wymienić także mało znane na Zachodzie prace badaczy wschodnio- i środkowoeuropejskich, np. rozprawy powstałe $\mathrm{w}$ ramach seminariów prowadzonych przez Wilena Komissarowa, skupionych wokół historii myśli przekładoznawczej Francji i Kanady (Kalinin 1999), Stanów Zjednoczonych (Polyutova 1999) oraz Wielkiej Brytanii (Ubozhenko 2000) - wydana również w postaci monografii (Ubozhenko 2014). Sam Komissarow jest autorem opracowań prezentujących dziedzictwo światowej (Komissarov 2002a) i rodzimej (Komissarov 2002b) refleksji nad przekładem. Dorobek rosyjskojęzycznej nauki o przekładzie próbowali przybliżyć także polscy przekładoznawcy (Szczerbowski 2011; Bednarczyk 2016). Badania tego rodzaju, choć wycinkowe, stanowią fundament dla transnarodowej syntezy badań nad przekładem.

Na obecnym etapie rozwoju nauka o przekładzie wciąż domaga się pogłębionej metarefleksji nad skumulowaną na przestrzeni wieków wiedzą. Ba- 
dania historyczne motywuje obserwowany od lat 90. jej gwałtowny przyrost. W przypadku przekładoznawstwa rosyjskojęzycznego wiedza ta, co wydaje się absurdalne, spowodowała pewien impas, w którym znalazło się przekładoznawstwo przytłoczone wzmożonym strumieniem informacyjnym. Rosyjscy badacze starszego pokolenia z początkiem obecnego stulecia zaczęli żywić poważne obawy, czy nauka o przekładzie nie wyczerpała swojego potencjału (patrz np. Tsvilling 2002; Latyshev 2013). Takie obawy mogą być objawem kryzysu dyscypliny. W Kuhnowskiej relatywistycznej filozofii nauki kryzys należy do jednego $\mathrm{z}$ etapów trójfazowych cyklów rozwojowych różnych gałęzi nauki: nauka normalna ${ }^{6}$ - kryzys - rewolucja (Kuhn 1996/2009; Strawiński 2011: 329). Być może obecny kryzys zwiastuje rewolucję w nauce o przekładzie.

Kwestią fundamentalną z metodologicznego punktu widzenia jest wyodrębnienie wśród badań historycznych prowadzonych $\mathrm{w}$ ramach nauki o przekładzie następujących obszarów: 1) historii przekładuㄱ; 2) historii działalności translatorskiej (tłumaczy); 3) historii myśli krytycznej nt. przekładu; oraz 4) historii (a właściwie historiografii ${ }^{8}$ ) nauki o przekładzie.

Mimo że obszary wymienionych wyżej badań nad przeszłością są organicznie ze sobą związane, wszystkie wymagają przyjęcia perspektywy historycznej, każdy z nich de facto ma inny obiekt badań, implikujący dalej odmienny sposób jego oglądu. Obiektem historii przekładu jest finalny produkt działalności translatorskiej. Celem związanych z nim badań jest poszukiwanie odpowiedzi na pytania: co było przekładane, kiedy, przez kogo, dla jakiego kręgu odbiorców, na czyje zlecenie, w jaki sposób, w jakim kontekście społeczno-politycznym 9 . Historia tłumaczy wymaga nie tylko znajomości tła społeczno-politycznego konkretnych epok, ale również analizy kontekstu biograficznego pośredników językowych. Obiektem badań na tej płaszczyź-

${ }^{6}$ Pojęcie „nauka normalna” u Kuhna oznacza „badania wyrastające z jednego lub wielu takich osiągnięć naukowych przeszłości, które dana społeczność uczonych aktualnie akceptuje i traktuje jako fundament swej dalszej praktyki" (Kuhn 1996/2009: 32) i ściśle wiąże się z innym wprowadzonym do nauki przez badacza terminem „paradygmat”, który ma „wskazywać na to, że pewne akceptowalne wzory faktycznej praktyki naukowej - wzory obejmujące równocześnie prawa, teorie, zastosowania i wyposażenie techniczne - tworzą model, z którego wyłania się jakaś szczególna, zwarta tradycja badań naukowych" (tamże: 33).

7 Ten obszar badań bywa również określany archeologią przekładu (zob. St-Pierre 1993; Pym 1998).

${ }^{8}$ Jak podkreśla Woleński, i należy się z tym zgodzić, termin „historia” jest dwuznaczny. Z jednej strony, znaczy tyle co słowo „dzieje”, z drugiej zaś jest równoważny terminowi „historiografia”, oznaczającemu opis tych dziejów (Woleński 2014: 107).

9 Zob. np. Gotsiridze, Khukhuni 1986; van Hoof 1991; Venuti 1995. 
nie jest tłumacz jako agens $\mathrm{w}$ przestrzeni społecznej ${ }^{10}$. O ile $\mathrm{w}$ pierwszym przypadku dominuje podejście typowo tekstocentryczne, drugie można zdefiniować jako agensocentryczne. Obiektem badań ulokowanych w trzecim z obszarów jest myśl krytyczna (nienaukowa ${ }^{11}$ ) o przekładzie, celem zaś ustalenie, jak współcześni wypowiadali się o przekładach i ich twórcach, i jak sami tłumacze wypowiadali się o swojej twórczości ${ }^{12}$. Podstawowym źródłem tak zorientowanych badań są recenzje przekładów, szkice krytyczne oraz materiał w postaci paratekstów, takich jak komentarze, przedmowy czy posłowia do tłumaczeń. Obiektem badań prowadzonych w czwartym obszarze jest nauka o przekładzie, celem natomiast stworzenie historiografii tekstów naukowych o przekładzie. Pole badawcze charakteryzuje podejście naukocentryczne. Ten ostatni z obszarów chciałabym uczynić przedmiotem dalszej refleksji.

Dzieje nauki, w tym i nauki o przekładzie, są przedmiotem zainteresowania wielu dyscyplin, mogą być rozpatrywane na gruncie historii, filozofii nauki, naukoznawstwa, ogólnej teorii kultury, a także jako dział dyscypliny, której omówienie dotyczy. Nauka o przekładzie jak dotąd była przedmiotem metarefleksji podejmowanych na swoim własnym gruncie.

Mimo że debata epistemologiczna przekładoznawców na temat osiągnięć i ewolucji dyscypliny toczy się już od pewnego czasu (zob. Pym 1998; Bandia, Bastin 2006; Kostikova 2011; D’hulst, Gambier 2018; Rundle 2014; 2019), jak dotąd brak wyraźnych propozycji konceptualnych badań. Tradycyjne metodologie badań przekładoznawczych nie mają $\mathrm{w}$ tym przypadku zastosowania. Badanie przeszłości dyscypliny może odbywać się z wielu perspektyw. Na kształt podejmowanych w tym zakresie inicjatyw naukowych wpływa wiele czynników, przede wszystkim cele, jakie stawia sobie podmiot poznający (badacz), dostęp do źródeł i narzędzi badawczych, zasięg planowanego przedsięwzięcia naukowego (lokalny lub transnarodowy) itp. W związku z powyższym nie ma, i z definicji nie może być, gotowych procedur radzenia sobie z historią wiedzy o przekładzie (D’hulst, Gambier 2018: 9).

Ogólne założenia metodologiczne badań nad dziejami nauki o przekładzie zasadniczo nie powinny różnić się od metodologii przyjętych w historiografii innych nauk. Różnice mogą dotyczyć jedynie dyferencjalnych cech dyscypliny, na podstawie których możemy ją ukonstytuować jako odrębną dziedzinę wiedzy, np. podstaw teoretycznych, pól badawczych, kontekstu funkcjonowania nauki.

10 Zob. np. Delisle, Woddworth 2012; o tłumaczu jako agensie zob. Heydel 2009: 29.

${ }^{11}$ Szerzej zob. Lewicki 2017: 38-39.

12 Zob. np. Levin, Fedorov 1960; Balcerzan 1977; Balcerzan, Rajewska 2007. 
Podejmując refleksję na poziomie meta, należy wytłumaczyć się najpierw z tego, jak ujmujemy główny obiekt badań translatorycznych. Fenomen przekładu bywa bowiem przez różnie zorientowanych badaczy rozpatrywany szeroko: jako 1) proces językowy i mentalny w całej swej złożoności i uwarunkowaniach komunikacyjnych wykonywany przez człowieka i maszynę; 2) rezultat działalności translatorskiej, tj. obiekt materialny - tekst przekładu, badany i oceniany w systemie jego relacji do tekstu wyjściowego i byt samoistny stanowiący nieodłączny element kultury przyjmującej, dzieło o określonej recepcji w polisystemie literatury i kultury docelowej, które ma swoją historię i na które istnieje pewne zapotrzebowanie społeczne; 3) przedmiot dydaktyki uniwersyteckiej (Konefał 2016: 15).

Wielowymiarowość przekładu jako obiektu lub przedmiotu badań sytuuje go w obszarze zainteresowań różnych dziedzin nauki, od podstawowych dla przekładoznawstwa nauk filologicznych, poprzez nauki pedagogiczne, po odległe nauki matematyczne i techniczne. To w dziedzinach fundujących, przede wszystkim językoznawstwie i literaturoznawstwie, konstytuujące się przekładoznawstwo poszukiwało tożsamości metodologicznej, później inspiracje zaczęto czerpać również z psychologii, filozofii, wiedzy o kulturze i innych nauk. Dlatego niezmiernie ważne jest uwzględnienie transferu wiedzy i narzędzi badawczych innych nauk. Holistyczna historiografia myśli translatorskiej powinna integrować wyniki polidyscyplinarnej refleksji.

Usystematyzowanie i ocena tak różnie zorientowanej wiedzy nt. przekładu są na obecnym etapie rozwoju przekładoznawstwa konieczne. Potrzeba metarefleksji może być dwojako motywowana, jak twierdzi Marek Kolasa, może ona

wypływać z pobudek pragmatycznych, gdy celem jest doskonalenie kompetencji w zakresie własnej dyscypliny (refleksja przedmiotowa), bądź mieć źródła głębsze, epistemologiczno-antropologiczne (refleksja podmiotowa). W pierwszym znaczeniu przedmiot poznania ulokowany jest w obrębie nauki macierzystej (zwykle jako subdyscyplina, np. historia historiografii), w drugim wchodzi w zakres naukoznawstwa lub filozofii nauki. Obie perspektywy są komplementarne i prowadzą do innych rezultatów. Refleksja przedmiotowa pozwala na wnioski głębsze, jednakże traci z pola widzenia kwestie ogólne i interdyscyplinarne (w tym zapożyczenia), z kolei podejście metanaukowe eksponuje pojęcia uniwersalne i pozwala przekroczyć barierę macierzystej dyscypliny, lecz jest jednocześnie mało konkretne. We współczesnej nauce sztywny podział obu perspektyw wydaje się jednak niemożliwy do utrzymania (Kolasa 2013: 5). 
Optymalne byłoby więc wykorzystanie obu tradycji.

Zadaniem historiografii nauki winno być „odtworzenie przebiegu historycznego rozwoju nauki” (Woleński 2014: 103). We współczesnych badaniach historiograficznych dominują trzy wyodrębnione przez A. Munslowa podstawowe podejścia do przeszłości (metaperspektywy):

(1) Podejście rekonstrukcyjne, które można utożsamić z filozoficznym naiwnym realizmem. Zakłada ono, że przeszłość można opisać „taką jaka rzeczywiście była” na podstawie „krytycznego oglądu źródeł”. Podejście to neguje potrzebę teorii i metodologii w refleksji historycznej, gdyż „przeszłość” jest poznawalna za pomocą potocznych kategorii myślowych. (2) Podejście konstrukcyjne, którego jednymi z pierwszych przedstawicieli byli K. Marks i H. Spencer, akcentuje potrzebę oparcia wiedzy o przeszłości na silnych konstrukcjach teoretycznych. W tym podejściu przeszłość jest poznawalna pod postacią fragmentarycznych informacji, którym sens i spójność nadaje współczesna teoria. (3) Podejście dekonstrukcjonistyczne czyni przedmiotem poznania nie samą przeszłość - gdyż jest ona niepoznawalna, lecz obecność jej różnorakich śladów i opisów w teraźniejszości. Zadaniem refleksji historycznej staje się tutaj zrozumienie znaczenia roli „świadomości przeszłości” w teraźniejszości (Munslow 1997: 17-36 za: Werner 2009: 16).

Podejście rekonstrukcyjne sprowadza rolę historyka do zwykłego archiwisty. Punktem wyjścia w refleksji metodologicznej nt. historii nauki o przekładzie może być oparte na myśli postmodernistycznej podejście dekonstrukcjonistyczne. Zwolennikiem takiego podejścia w badaniu historii nauki o przekładzie jest np. Paul Bandia, szukający inspiracji metodologicznych u M. Foucaulta i J. Derridy (Bandia 2006).

Badania zmierzające ku syntezie wiedzy naukowej o przekładzie powinny być poprzedzone pracami dokumentacyjnymi. Elementarnym i niezmiernie ważnym, choć pełniącym funkcje pomocnicze, narzędziem badacza dziejów nauki o przekładzie powinna stać się pełna retrospektywna bibliografia dziedzinowa jako podstawowa baza empiryczna badań. Z punktu widzenia historii nauki do najistotniejszych zadań bibliografii należą jej funkcje dokumentacyjno-historyczne wobec własnej dziedziny - jest „świadectwem” jej rozwoju, osiągnięć i stanu obecnego, a próby jej tworzenia można uznać za świadectwo zaawansowania badań prowadzonych $\mathrm{w}$ ramach danej dyscypliny (zob. Matczuk 2014: 200).

Potrzebę stworzenia pełnej bibliografii jako pierwszego etapu na drodze do opracowania historii światowej translatologii dostrzegał już w latach 60. i 80. ubiegłego stulecia węgierski teoretyk przekładu György Radó 
(1967). Ambicją badacza były usystematyzowanie i rejestracja zarówno wytworów działalności translatorskiej, tj. przekładów obcych literatur, jak i piśmiennictwa związanego z naukową refleksją o przekładzie. L. van Doorslaer zwraca uwagę, że od początku swojej historii dyscyplina tłumaczeń wymagała narzędzia systematyzującego, nawet w fazie, w której jej wiedza nie była wcale tak obszerna jak obecnie (van Doorslaer 2011: 13). Za pionierską uważana jest bibliografia E. Nidy załączona do monografii Toward a Science of Translating (1964).

Bibliografia nauki o przekładzie powinna rejestrować wszelkiego rodzaju strumienie informacyjne w postaci piśmiennictwa naukowego - dysertacji, monografii, literatury o charakterze dydaktycznym, opracowań zbiorowych oraz artykułów publikowanych na łamach czasopism branżowych i w pracach zbiorowych. Podstawowym źródłem - w mojej ocenie - powinny stać się rozprawy naukowe przedkładane w celu uzyskania awansu naukowego, ponieważ to właśnie one w największym stopniu odzwierciedlają aktualne $\mathrm{w}$ danym okresie tendencje w nauce.

Prace dokumentacyjne mają kluczowe znaczenie jako punkt odniesienia do dalszych opracowań koncepcyjnych. Szczegółowa analiza danych bibliograficznych pozwala bowiem na: 1) prześledzenie etapów ewolucji badań nad przekładem, w tym momentów tzw. zwrotów paradygmatycznych, na tle ogólnych tendencji w nauce; 2) określenie możliwości transgranicznych dialogów pomiędzy dyscyplinami zainteresowanymi przekładem/tłumaczeniem; 3) identyfikację głównych pól badawczych, a następnie wskazanie obszarów zarówno nadmiernie eksploatowanych, jak i w niewystarczającym stopniu zbadanych lub niezbadanych zupełnie; 4) zdefiniowanie instytucjonalnej struktury nauki poprzez wskazanie aktywności powiązanych z nią badaczy i ośrodków, instytucji naukowo-badawczych oraz uczelni wyższych, redakcji czasopism, wydawnictw itd.

Niestety tworzone online od lat 90 . wielkie bazy bibliograficzne takie jak $\mathrm{TSB}^{13}$, BITRA ${ }^{14}$ nie są w stanie zarejestrować całego dorobku. Wadą ich jest poza tym wybiórczość, obejmują bowiem głównie piśmiennictwo anglojęzyczne wydawane na terytorium Ameryki Północnej i Europy Zachodniej. Publikacje powstałe na terenie Europy Wschodniej i Azji, w tym w Rosji/ ZSRR, są przez nie rejestrowane $w$ niewielkim stopniu. Wymienione wyżej źródła bibliograficzne nie mogą więc być wykorzystane do analizy dorobku

${ }_{13}$ Translation Studies Bibliography, https://benjamins.com/online/tsb/.

${ }^{14}$ Bibliography of Interpreting and Translation, https://dti.ua.es/en/bitra/introduction. html. 
badaczy wymienionych obszarów ani też w realizacji projektów o zasięgu transnarodowym. Przed historykiem nauki o przekładzie stoi więc zadanie stworzenia pełnej retrospektywnej bazy dziedzinowej dla badanego obszaru/ okresu.

Kompletna baza bibliograficzna pozwala $\mathrm{z}$ kolei na przeprowadzenie rzetelnej analizy bibliometrycznej (scientometrycznej), która coraz chętniej wykorzystywana jest w analizie poszczególnych dyscyplin naukowych (zob. Kolasa 2013), również dorobku światowej translatologii (zob. Pöchhacker 1995; Gile 2001; Grbić, Pöllabauer 2008; Grbić 2013; Rovira-Esteva, Aixelà 2018).

Bibliografia jest więc źródłem do dalszej refleksji przedmiotowej i podmiotowej, a także pozwala zgłębić aspekty socjologiczne ewolucji nauki o przekładzie.

\section{Literatura}

Alekseyev M. P., 1931, Problemy khudozhestvennogo perevoda. Vstupitel'naya lektsiya v Irkutskom gosudarstvennom universitete 15 dekabrya 1927 goda, Irkutsk [Алексеев, М. П., 1931, Проблемы художественного перевода. Вступительная лекция в Иркутском государственном университете 15 декабря 1927 года, Иркутск].

Baker M., Saldanha G. (red.), 1998/2009/2019, Routledge Encyclopedia of Translation Studies, London-New York.

Balcerzan E., 1977, Pisarze polscy o sztuce przekładu. 1440-1974. Antologia, Poznań.

Balcerzan E., Rajewska E., 2007, Pisarze polscy o sztuce przekładu. 1440-2005. Antologia, Poznań.

Bassnett S., 2005, Translation studies, Third edition, London-New York.

Bassnett S., Lefevere A., 1990, Translation, History and Culture, London-New York.

Bandia P. F., 2006, The Impact of Postmodern Discourse on the History of Translation, [w:] Charting the Future of Translation History, G. L. Bastin, P. F. Bandia (red.), Ottawa, s. 45-58.

Bednarczyk A., 2016, Zmagania z przekładem w przestrzeni rosyjskojęzycznej. Teoria i praktyka w ewolucji, Gdańsk.

Berman A., 1984, L'Épreuve de l'étranger. Culture et traduction dans l'Allemagne romantique, Paris.

Chistovich I. A., 1873, Istoriya perevoda Biblii na russkiy yazyk, Sankt-Peter- 
burg [Чистович И. А., 1873, История перевода Библии на русский язык, Санкт-Петербург].

Delisle J., Woodsworth J., 2012, Translators through History. Revised edition, Amsterdam-Philadelphia.

Delisle J., Woodsworth J., 2014, Les traducteurs dans l'histoire, $3^{e}$ éd, Paris.

D’hulst L., 2010, Translation history, [w:] Handbook of Translation Studies,

t. 1, Y. Gambier, L. van Doorslaer (red.), Amsterdam-Philadelphia, s. 397-405.

D'hulst L., 2015, Quels défis pour l'histoire de la traduction et de la traductologie?, „Meta”, 60(2), s. 281-298.

D’hulst L., Gambier Y., 2018, General Introduction, [w:] A History of Modern Translation Knowledge: Sources, Concepts, Effects, L. D’hulst and Y. Gambier (red.), Amsterdam, s. 1-14.

Doorslaer L. van, Bibliographies of translation studies, [w:] Handbook of Translation Studies, t. 2, Y. Gambier, L. van Doorslaer (red.), s. 13-16.

Fedorov A. V., 1953, Vvedeniye v teoriyu perevoda, Moskva [Федоров A. B., 1953, Введение в теорию перевода, Москва].

Garbovskiy N. K., 2004, Teoriya perevoda, Moskva [Гарбовский Н. К., 2004, Теория перевода, Москва].

Genzen A., 1884, Istoriya slavyanskogo perevoda simvolov very, Sankt-Peterburg [Гензен А., 1884, История славянского перевода символов веры, Санкт-Петербург].

Gotsiridze D. Z., Khukhuni G. T., 1986, Ocherki po istorii zapadnoyevropeǐskogo i russkogo perevoda, Tbilisi [Гоциридзе Д. 3., Хухуни Г. Т., 1986, Очерки по истории западноевропейского и русского перевода, Тбилиси].

Grbić N., 2013, Bibliometrics, [w:] Handbook of Translation Studies, t. 4, Y. Gambier and L. van Doorslaer (red.), Amsterdam, s. 20-24.

Gruzinskiy A. S., 1912, Iz istorii perevoda Yevangeliya v Yuzhnoy Rossii v XVI veke. Letkovskoye yevangeliye (opisaniye, sostav Yevangeliya, yazyk, analiz vstavki. Prilozheniya i varianty), Kiyev [Грузинский А. С., 1912, Из истории перевода Евангелия в Южной России в XVI веке. Летковское евангелие (описание, состав Евангелия, язык, анализ вставки. Приложения и варианты), Киев].

Heydel M., 2009, Zwrot kulturowy w badaniach nad przekładem, „Teksty Drugie", 6, s. 21-33.

Kalinin I. V., 1999, Sovremennoye perevodovedeniye Frantsii i Kanady (kontseptual'no-istoricheskoye issledovaniye): avtoref. dis. ... kand. filol. nauk, Moskva [Калинин И. В., 1999, Современное переводоведение 
Франции и Канады (концептуально-историческое исследование): автореф. дис. ... канд. филол. наук, Москва].

Khukhuni G. T., 1990, Russkaya i zapadnoyevropeyskaya perevodcheskaya mysl' (osnovnyye tendentsii v razvitii nachala KHKH v.), Tbilisi [Хухуни Г. Т., 1990, Русская и западноевропейская переводческая мысль (основные тенденции в развитии начала XX в.), Тбилиси].

Kolasa W. M., 2013, Historiografia prasy polskiej (do 1918 r.). Naukometryczna analiza dyscypliny 1945-2009, Kraków.

Komissarov V. N., 2002a, Lingvisticheskoye perevodovedeniye v Rossii, Moskva [Комиссаров В. Н., 2002a, Лингвистическое переводоведение в России, Москва].

Komissarov V. N., 2002b, Sovremennoye perevodovedeniye, Moskva [Комиссаров В. Н., 2002b, Современное переводоведение, Москва]. Konefał E., 2016, Przekładoznawstwo rosyjskie. T. 1: Autoreferaty dysertacji 1937-2015, Gdańsk.

Kopanev P. I., 1972, Voprosy istorii i teorii khudozhestvennogo perevoda, Minsk [Копанев П. И., 1972, Вопросы истории и теории художественного перевода, Минск].

Kostikova O. I., 2011, Istoriya perevoda: predmet, metodologiya, mesto v nauke o perevode, „Vestnik moskovskogo universiteta. Seriya 22. Teoriya perevoda", 2, s. 3-22 [Костикова О. И., 2011, История перевода: предмет, методология, место в науке о переводе, „Вестник московского университета. Серия 22. Теория перевода”, 2, s. 3-22].

Kuhn T. S., 2009, Struktura rewolucji naukowych, tł. H. Ostromęcka, J. Nowotniak, Warszawa [podstawa przekładu: Kuhn T. S., 1996, The structure of Scientific Revolutions, 3rd ed., Chicago-London].

Latyshev L. K., 2013, Perevodovedeniye: Perevodovedeniye: aspekty i perspektivy razvitiya, „Vestnik MGOU”, 1, s. 1-13 [Латышев Л. К., Переводоведение: аспекты и перспективы развития, „Вестник МГОУ”, 1, s. 1-13], https://evestnik-mgou.ru/vi/Issues/View/11 (dostęp: 11.04.2019).

Lefevere A. (red.), 1992, Translation. History. Culture, London-New York.

Lewicki R., 2017, Zagadnienia lingwistyki przekładu, Lublin.

Levin Yu. D., 1962, Ob istorizme $\mathrm{v}$ podkhode $\mathrm{k}$ istorii perevoda, [w:] Masterstvo perevoda, nr 2, s. 373-392 [Левин Ю. Д., 1962, Об историзме в подходе к истории перевода, [w:] Мастерство перевода, $\mathrm{nr} 2$, s. 373-392].

Levin Yu. D., 1963, Ob istoricheskoy evolyutsii printsipov perevoda ( $\mathrm{k}$ istorii perevodcheskoy mysli v Rossii), [w:] Mezhdunarodnyye svyazi russkoy li- 
teratury, M. P. Alekseyev (red.), Moskva-Leningrad, s. 5-63 [Левин Ю. Д., 1963, Об исторической эволюции принципов перевода (к истории переводческой мысли в России), [w:] Международные связи русской литературы, ред. М. П. Алексеев, Москва-Ленинград, s. 5-63].

Levin Yu. D., Fedorov A. V., 1960, Russkiye pisateli o perevode (XVIII-XX vv.), Leningrad [Левин Ю. Д., Федоров А. В., 1960, Русские писатели о переводе (XVIII-XX вв.), Ленинград].

Hajduk Z., 1996, Niektóre sposoby uzasadniania teorii metodologicznych, „Filozofia Nauki”, 4/3, s. 87-94.

Hoof H. van, 1991, Histoire de la traduction en occident, Paris.

Modestov V. S., 2006, Khudozhestvennyy perevod: istoriya, teoriya, praktika, Moskva [Модестов В. С., 2006, Художественный перевод: история, теория, практика, Москва].

Munday J., 2001/2008, Introducing translation studies. Theories and applications, London - New York.

Munslow A., 1997, Deconstructing history, London.

Nida E. A., 1964, Toward a Science of Translating. With Special Reference to Principles and Procedures Involved in Bible Translating, Leiden.

Norlie O., 1934, The Translated Bible. 1534-1934, Philadelphia.

Ojcewicz G., 1991, Podstawy translatoryki, Gdańsk.

Olohan M., 2014, History of science and history of translation: disciplinary commensurability?, „Translator”, 20(1), s. 9-25.

Pöchhacker F., 1995, Writings and Research on Interpreting: A Bibliographic Analysis, „The Interpreters' Newsletter”, 6, s. 17-31.

Polyutova O. N., 1999, Kontseptual'no-istoricheskoye issledovaniye perevodovedeniya v SSHA: avtoref. dis. ... kand. filol. nauk, Moskva [Полютова О. Н., 1999, Концептуально-историческое исследование переводоведения в США: автореф. дис. ... канд. филол. наук, Москва].

Pomorski J., 2004, Punkt widzenia we współczesnej historiografii, [w:] Punkt widzenia w języku i w kulturze, J. Bartmiński, S. Niebrzegowska-Bartmińska, R. Nycz (red.), Lublin, s. 11-32.

Pym A., 1998, Method in Translation History, Manchester.

Radó G., 1967, Approaching the History of Translation, „Babel”, 13(3), s. $169-173$.

Radó G., 1985, Basic Principles and Organized Research of the History, Theory and History of Theory of Translation, [w:] Der Übersetzer und seine Stellung in der Öffentlichkeit: X. Weltkongress der FIT, ed. H. Bühler, Wien, s. 305-308. 
Rener F. M., 1989, Interpretatio: Language and Translation from Cicero to Tytler, Amsterdam-Atlanta.

Rizhskiy M. I., 1978, Istoriya perevodov Biblii v Rossii, Novosibirsk [Рижский М. И., 1978, История переводов Библии в России, Новосибирск].

Rossel's Vl., 1964, Nuzhna istoriya khudozhestvennogo perevoda v SSSR?, [w:] Masterstvo perevoda, s. 53-62 [Россельс Вл., 1964, Нужна история художественного перевода в СССР?, [w:] Мастерство перевода, s. 53-62].

Rovira-Esteva S., Aixelà J. F., 2018, Bibliometric tools. Evaluation, mapping, [w:] A History of Modern Translation Knowledge, L. D’hulst, Y. Gambier (red.), Amsterdam, s. 117-122.

Rundle Ch., 2014, Theories and methodologies of translation history: the value of an interdisciplinary approach, „Translator”, 20(1), s. 2-8.

Rundle Ch., 2018, Temporality, [w:] A History of Modern Translation Knowledge: Sources, Concepts, Effects, L. D’hulst, Y. Gambier (red.), Amsterdam, s. 235-245.

Rundle Ch., 2019, Historiography, [w:] Routledge Encyclopedia of Translation Studies, $3^{\text {rd }}$ Edition, M. Baker and G. Saldanha (red.), London-New York, https://www.researchgate.net/publication/323018307_Historiography (dostęp: 5.05.2019).

Schippel L., Zwischenberger C. (red.), 2017, Going East: Discovering New and Alternative Traditions in Translation Studies, Berlin.

Sdobnikov V. V., Petrova O. V., 2006, Teoriya perevoda, Moskva [Сдобников В. В., Петрова О. В., 2006, Теория перевода, Москва].

Shadrin V. I., 2017, Universitet-skoye perevodovedeniye, Sankt Peterburg [Шадрин В. И., 2017, Университетское переводоведение, Санкт Петербург].

Shor V., 1973, Kak pisat' istoriyu perevoda?, [w:] Masterstvo perevoda, 9, s. 277-295 [Шор В., 1973, Как писать историю перевода?, [w:] Мастерство перевода, 9, s. 277-295].

Smirnov A. A., Alekseyev M. P., 1934, Perevod, [w:] Literaturnaya entsiklopediya, T. 8, Moskva, s. 512-532 [Смирнов А. А., Алексеев М. П., 1934, Перевод, [w:] Литературная энциклопедия, Т. 8, Москва, s. 512-532].

St. André, History, [w:] The Routledge Encyclopedia of Translation Studies, 2nd ed., ed. by M. Baker and G. Saldanha, London-New York, s. 133-136. St-Pierre P., 1993, Translation as a Discourse of History, TTR, t. 6, nr 1, s. $61-82$.

Steiner G., 1975, After Babel. Aspects of Language and Translation, New York [Polskie tłumaczenie: Steiner G., 2018, Po wieży Babel. Aspekty języka 
i przekładu, wyd. drugie poprawione, przekład i posłowie O. i W. Kubińscy, Warszawa].

Strawiński W., 2011, Funkcja i cele nauki - zarys problematyki metodologicznej, „Zagadnienia naukoznawstwa”, 3(189), s. 323-335.

Szczerbowski T., 2011, Rosyjskie teorie przekładu literackiego, Kraków.

Torop P., 2008, Przekład całkowity, [w:] P. Ricœur, P. Torop, O tłumaczeniu, tłum. T. Swoboda, S. Ulaszek, Gdańsk, s. 63-327.

Tsvilling M. Ya., 2002, Ischerpala li teoriya perevoda svoi vozmozhnosti?, „Voprosy filologii”, 1, s. 48-50 [Цвиллинг М. Я., 2002, Исчерпала ли теория перевода свои возможности?, „Вопросы филологии”, 1, s. $48-50]$.

Tyulenev S. V., 2004, Teoriya perevoda, Moskva [Тюленев C. В., 2004, Теория перевода, Москва].

Ubozhenko I. V., 2000, Teoreticheskiye osnovy lingvisticheskogo perevodovedeniya v Velikobritanii: avtoref. dis. ... kand. filol. nauk, Moskva [Убоженко И. В., 2000, Теоретические основы лингвистического переводоведения в Великобритании: автореф. дис. ... канд. филол. наук, Москва].

Ubozhenko I. V., 2014, Zarubezhnoye perevodovedeniye. Velikobritaniya, Moskva [Убоженко И. В., 2014, Зарубежное переводоведение. Великобритания, Москва].

Venuti L., 1995, The Translator's Invisibility. A History of Translation, London-New York.

Venuti L. (red.), 2012, The Translation Studies Reader, 3rd ed., London-New York.

Vernadskiy V. I., 1988, Kant i yestestvoznaniye, [w:] tegoż, Trudy po vseobshchey istorii nauki, izd. 2-ye, Moskva, s. 178-200 [Вернадский В. И., 1988, Кант и естествознание, [w:] tegoż, Труды по всеобщей истории науки, изд. 2-е, Москва, s. 178-200] [przedruk artykułu z 1904 r.].

Weissbort D., Eysteinsson A. (red.), 2006, Translation - Theory and Practice. A Historical Reader, Oxford.

White H., 2002, The Historical Text as Literary Artifact, [w:] Narrative Dynamics: Essays on Time, Plot, Closure, and Frames, B. Richardson (red.), Columbus, s. 191-210.

Werner W., 2009, Historyczność kultury. W poszukiwaniu myślowego fundamentu współczesnej historiografii, Poznań.

Woleński J., 2014, Filozofia nauki a historia nauki, „Prace Komisji Historii Nauki PAU', XIII, s. 99-115.

Yevseyev I. Ye., 1916, Ocherki po istorii slavyanskogo perevoda Biblii, Petro- 
grad [Евсеев И. Е., 1916, Очерки по истории славянского перевода Библии, Петроград].

\section{In search for methodology of metatranslation studies}

\section{Summary}

This paper is an attempt at the definition of methodological research frameworks on the history of Translation Studies. The most relevant strategy would be a combination of the historical perspective with methods applied in science studies and philosophy of science. A comprehensive retrospective field literature sources should form a background for further analysis and synthesis; this would allow to consolidate knowledge related to translation studies that is now unevenly distributed in many paradigms developed within a variety of disciplines, to identify major research fields and issues and to determine the qualitative and quantitative level of their development.

Keywords: Translation Studies, history of translation, methodology of historical and translation research, field literature reference sources, bibliometrics 